

\title{
Developing Students' Research Skills with Adapted Primary Literature
}

\author{
Toni Hidayat ${ }^{1 *}$, Nuryani Rustaman ${ }^{2}$, Parsaoran Siahaan ${ }^{3}$ \\ ${ }^{1,2,3}$ Science Education Departement, Postgraduate School, Universitas Pendidikan Indonesia, \\ Jl. Dr. Setiabudi No. 229, Bandung 40154, Indonesia \\ *Correspondence: tonihidayatbinhasan@gmail.com
}

\begin{tabular}{ll}
\hline Abstract \\
\hline Keywords: & There is a gap between the quantity and quality of research in Indonesia. It is assumed \\
Adapted Primary & that the research skills of the researchers are still low. Meanwhile, research skills \\
Literature, & development still relies on the higher education level. Efforts are needed to develop \\
Authentic Science, & research skills from an early age. This study aims to examine the use of APL in the \\
Research Skills & authentic science approach to develop research skills of junior high school students. \\
& The quasi-experimental method was carried out by inviting 81 students from two \\
classes of 7th grade in a state middle school in Bandung, Indonesia. They analyzed & three Adapted Primary Literatures with the jigsaw and NHT models. Before and after \\
learning, students took research skills tests. The research instrument has passed the \\
validity and reliability tests. Descriptive and inferential analyses were done. The \\
results of data analysis indicate that the use of APL in the authentic science approach \\
in both learning models can develop students' research skills. Furthermore, the jigsaw \\
model is more recommended to use. This study recommends the use of APL as a \\
science learning resource to develop students' research skills as a beginning to \\
introduce the scientific method.
\end{tabular}

To cite this article:

Hidayat, T., Rustaman, N., Siahaan, P. (2021). Developing Students' Research Skills with Adapted Primary Literature. Thabiea : Journal of Natural Science Teaching, 4(2), 121-135.

\section{Introduction}

Innovation has been making our life easier. Not only to fulfill our desires, but sometimes it is also needed to enable us to survive in a very hard situation. Debriefing young students with research skills in science online-learning, for instance, is very beneficial during a pandemic recently. The countries which carry out more research have a greater capacity to produce innovations (World Economic Forum, 2018). The number of research from those countries can be seen through the number of research articles published. While the quality of a scientific publication can be seen through its citation index value (Fatimah, 2018). Based on the number of research articles published in 2019, Indonesia is ranked 21st. This ranking has increased over the past 10 years from the 59th rank in 2009. However, Indonesia's citation index in 2019 is 5.00, so that Indonesia is in 47th place (Scimago Lab, 2018). This shows that Indonesian scientific publications are still lacking in quality (Ristekdikti, 2018).

Scientific publication as a way to disseminate research findings is one facet of research skills (Willison \& O'Regan, 2007). Therefore, it is assumed that the gap between the quantity and quality of Indonesian scientific publications is influenced by the low research skills level of the researchers. It turns out that the research skills of bachelor graduates are only in the medium category (Meerah et al., 2012). The lecture process also does not provide sufficient contribution in developing students' research skills (Subekti et al., 2018). 
Meanwhile, the development of research skills is still emphasized at the higher education levels (Meerah \& Arsad, 2010). Therefore, research skills development needs to be pursued since the previous education level (Landreau, 2011). Accordingly, it is known that the best time to learn is during childhood (Juhász \& Németh, 2018) and the best time to acquire new skills is during early adolescence (Janacsek et al., 2012). Thus, the development of research skills should at least begin with junior high school students.

The development of research skills can be achieved through research-based learning activities (Meerah \& Arsad, 2010; Odera et al., 2015; Rodríguez et al., 2019). However, teachers and students have limited time to conduct research-based learning (Meerah \& Arsad, 2010). Therefore, it is necessary to apply another learning approach as an alternative, but it is still linked to research activities conducted by scientists. One approach which can be applied is authentic science. In this approach, students can be involved in learning activities similar to how scientists work (Anker-Hansen \& Andrée, 2019; Chapman \& Feldman, 2017; Koomen et al., 2018; Machluf et al., 2017), experimenting and thinking (Labouta et al., 2018).

One strategy for achieving the authentic science approach is assigning students to analyze the Adapted Primary Literature (APL) (Hidayat et al., 2021). APL is an adaptation of the Primary Scientific Literature (PSL) (Yarden et al., 2015b). In the adaptation, the science language used is adjusted so that it can be more easily understood by secondary school students (Ariely et al., 2019). This is because PSL has a different scientific language when it is compared with the language of science in schools (Phillips \& Norris, 2009). Moreover, the language used in PSL is increasingly difficult to understand (Ball, 2017).

Even though it is an adaptation of scientific writings from scientists, APL can still increase the opportunity for students to conduct authentic scientific activities like those scientists do (Ford, 2009), so reading APL is considered an authentic scientific practice (Yarden et al., 2015a). The type, structure, and content of the writing and presentation of science in APL are maintained to be equal to PSL (Yarden, 2009). This allows students to continue to follow and learn the flow of reasoning and research. APL is also not only used to introduce scientific literature and scientific research processes to students (Koomen et al., 2016) but APL can also be used as a model of scientific reasoning (Ariely et al., 2019; Ford, 2009). In addition, science teachers at the secondary school level have a high perception of APL (Hidayat et al., 2020). They also have positive experiences when writing and implementing APL (Koomen et al., 2016). Thus, when APL is used as a science learning resource, APL is thought to be able to encourage the development of student research skills.

Research that describes the research skills profile of junior high school students in Indonesia appears to be still limited. However, research that describes the science process skills profile of junior high school students shows that their skill level is in a low category (Atmojo, 2012; Fatmawati \& Handhika, 2018; Rahman et al., 2017). Only 20-50\% of students have mastered science process skills (Siswanto et al., 2016). The profile of science process skills may be a predictor for the profile of research skills because the two are believed to have overlapping facets. With this research, it will be more obvious about the level of research skills of junior high school students and the efforts to develop them. One of the advantages of developing research skills is that it can also support students in the STEM field (Gilmore et al., 2015; Timmerman et al., 2013). 
This study aims to examine the use of APL in the authentic science approach to develop research skills of junior high school students. The research skills of students that are expected to develop are research skills at the level prescribed research in the most basic level of Willison and O'Regan Research Skills Development framework (Willison \& O'Regan, 2007). This level is possibly the most suitable to be used as a framework for developing research skills for junior high school students because their research skill level is presumably still low and most students do not have any experience in conducting research.

\section{Method}

With a quantitative approach, this study used a quasi-experimental method which has a pre-test, treatment, and post-test (Fraenkel et al., 2012). Two groups of 7th-grade students were invited to be involved in this study as participants. They totaled 81 students consisting of 42 males and 39 females. They were selected on the basis of their school's willingness to support this research. The school is located in Lembang, Bandung. This study was conducted in the even semester of the 2019/2020 academic year.

The instrument used was a research skills test. This test consists of 18 questions which are arranged based on the Research Skills Development framework at the prescribed research level (Willison \& O'Regan, 2007). The question is multiple choice with four options. Table 1 shows the rubrics of the test instruments. All items have passed the validity and reliability test with a significance level of 0.05 and $r_{\text {table }}$ of 0.254 .

Table 1. Instrument Rubrics of Research Skills Test

\begin{tabular}{|c|c|c|}
\hline Facet & Rubrics & $\begin{array}{l}\text { Number } \\
\text { of Items }\end{array}$ \\
\hline \multirow[t]{2}{*}{$\begin{array}{l}\text { Embark and } \\
\text { Clarify }\end{array}$} & $\begin{array}{l}\text { Students are able to respond to assignments or research questions } \\
\text { that emerge explicitly from the closed inquiry process. }\end{array}$ & 2 \\
\hline & $\begin{array}{l}\text { Students are able to clarify questions, terms and research } \\
\text { expectations. }\end{array}$ & 1 \\
\hline \multirow[t]{2}{*}{$\begin{array}{l}\text { Find and } \\
\text { Generate }\end{array}$} & $\begin{array}{l}\text { Students are able to determine how to collect data or information } \\
\text { from predetermined sources, where the data or information can } \\
\text { clearly be evidence. }\end{array}$ & 1 \\
\hline & $\begin{array}{l}\text { Students are able to record data or information using a } \\
\text { predetermined methodology from a predetermined source, where } \\
\text { the data or information can clearly be evidence. }\end{array}$ & 1 \\
\hline \multirow[t]{2}{*}{$\begin{array}{l}\text { Evaluate and } \\
\text { Reflect }\end{array}$} & $\begin{array}{l}\text { Students are able to evaluate data or information using simple } \\
\text { predetermined criteria. }\end{array}$ & 1 \\
\hline & $\begin{array}{l}\text { Students are able to reflect on the research process using simple } \\
\text { predetermined criteria. }\end{array}$ & 2 \\
\hline \multirow[t]{2}{*}{$\begin{array}{l}\text { Organise and } \\
\text { Manage }\end{array}$} & $\begin{array}{l}\text { Students are able to organize data or information using a } \\
\text { predetermined structure. }\end{array}$ & 1 \\
\hline & Students are able to manage the linear research process provided. & 2 \\
\hline \multirow[t]{2}{*}{$\begin{array}{l}\text { Analyse and } \\
\text { Synthesise }\end{array}$} & $\begin{array}{l}\text { Students are able to analyse data or information in the specified } \\
\text { format }\end{array}$ & 2 \\
\hline & $\begin{array}{l}\text { Students are able to synthesize data or information to reproduce } \\
\text { existing knowledge in a specified format. }\end{array}$ & 1 \\
\hline
\end{tabular}


Communicate Students are able to use mainly lay language and the type of and Apply language specified to show their understanding to the teacher as ethically an audience.

Students are able to apply the results of their research to a similar context in which knowledge is developed.

Students are able to follow research instructions related to ethnic, 1 social and cultural issues.

Early in March 2020, the first COVID-19 patient in Indonesia was detected. This pandemic is increasingly widespread in Indonesia. This condition forces learning to be shifted from school to home to suppress the spread of the virus. Therefore, all learning activity is performed online. Treatment, pre-test, and post-test in this study were also performed online. WhatsApp Group (WAG) was used to support the learning activity. It is considered the most effective media to support online learning in the early pandemic because it does not require a large data package and can share almost any file format (Wargadinata et al., 2020). It is also believed to use by all students. Meanwhile, the pre-test and post-test used Google Form - an online form that is believed to use by most teachers in assessing their student achievement. Perhaps, acquaintance with the media used can help this study runs as planned even in the mid of the pandemic.

Before the treatment was performed, students were invited to take a research skills test. The results of this test were considered pre-test scores. Then the treatment was performed in three meetings. This treatment was learning Science on the topic of environmental pollution by analyzing APL as a learning resource. The APL had the theme of soil, water, and air pollution. The APL is the result of an adaptation created by the researchers of this study from the PSL from the environmental engineering journal, from a local university. In the adaptation, not only the language was simplified but the layout design was also made more colorful to make it more appealing for students to read it.

The cooperative learning is considered as one way to optimize online learning (Silalahi \& Hutauruk, 2020). Cooperative learning might be able to promote research skills since in research some researchers work together collaboratively. Therefore, the first group of students applied the jigsaw model, while the second group applied the NHT model. These two models have been chosen in consideration of them as the most widely known cooperative learning models among science teachers. As the result, science teachers can be relatively more straightforward to apply the findings of this study in their classes later. In addition, when reading text is a main part of the learning activity, the jigsaw can be primarily used in the learning. It can improve students reading comprehension and learning outcomes. It can also enhance student motivation to learn Science and enhance student involvement in a learning activity. Meanwhile, the NHT can improve students' reading skills, improve student learning outcomes, and enhance student participation in learning (Hidayat et al., 2021).

In the two classes, the students were grouped. In the jigsaw class, each expert group analyzed and discussed different parts of APL, namely introduction, method, result, discussion, and conclusion. Then they came back to their respective home group and shared what they had obtained. This discussion was performed in each WAG of expert and home group. In the NHT class, a complete APL was distributed to each group. They analyzed and discussed the APL. At the end, a quiz was administered to check all group members' 
understanding. The scores they got were accumulated into group scores, so they had a responsibility to each group. This discussion was also performed on a WAG of each group. In the two classes, a worksheet for each meeting was provided as well to help students analyzing the three APL. All the learning activities were conducted synchronously. After the treatment was performed, students were again invited to take the research skills test. The results of this test were considered as post-test scores.

The pre-test and post-test scores are expressed on a scale of 100. The mean scores of students' research skills from both groups were compared with the categories in Table 2. This was done to determine the level of research skills of the students at the pre-test and post-test. Then, the score of research skills of the two groups was tested for normality and homogeneity. If the results show that the data is normally distributed and homogeneous, a parametric mean difference test will be performed. Otherwise, a non-parametric mean difference test will be performed (Minium et al., 1993). These analyses are assisted by SPSS software. The results of this mean difference test will be used to analyze the development of research skills in both classes and to conclude which model has a significant impact in developing research skills.

Table 2. Interpretation Guideline of Research Skills Level

\begin{tabular}{cc}
\hline Score of Research Skills & Category \\
\hline $0-19$ & Very Low \\
$20-39$ & Low \\
$40-59$ & Moderate \\
$60-79$ & High \\
$80-100$ & Very High \\
\hline
\end{tabular}

(Sugiyono, 2010)

The identity of the subjects and the name of the school are intentionally not disclosed to protect their privacy rights. We interacted with subjects after obtaining permission from the school. The data obtained from the subject is used only for the purposes of this study.

\section{Results and Discussion}

At the end of April 2020, students took a pre-test, but not all students took the test. The following week until early May 2020, students participated in science learning using APL. The first, second, and third meetings discussed soil, water, and air pollution respectively. Student participation in these lessons was assessed based on the number of posts they send on the WAG. There are students who are categorized as active, less active, and even not active. The following week the students took part in a post-test. Because not all students took part in the pre-test and post-test, and not all of them were active during learning, only 44 students were declared as active participants. In data analysis, only the data from these 44 students were analysed. Table 3 shows the data of the participants. 
Table 3. Participants

\begin{tabular}{lcc}
\hline Class and Gender & All Participant & Active Participant \\
\hline Class of Jigsaw & & \\
Male & 20 & 7 \\
Female & 21 & 10 \\
Class of NHT & & \\
Male & 22 & 14 \\
Female & 18 & 13 \\
\hline \multicolumn{1}{c}{ Total } & $\mathbf{8 1}$ & $\mathbf{4 4}$ \\
\hline
\end{tabular}

Some students are believed to come from low-income families. They have limited access to computers and the internet at home. Meanwhile, schools also cannot provide computers for students to use in their homes (Morgan, 2020). This drives us to students' participation problems. Actually, we have anticipated this problem. We recognized that online learning cannot provide a higher quality of interaction than the traditional one (Dumford \& Miller, 2018). Students were always reminded of the next lesson schedule. Every meeting was always preceded by filling in attendance to indicate that the lessons through this WAG were also recorded as their attendance in class as usual. However, it seems that the efforts made are not sufficient to make all students actively participate. If this research has sufficient sources, perhaps providing internet access facilities for each student can significantly increase student participation. Eventually, we assessed that the data from $54 \%$ of the students' numbers are sufficient for an analysis of their research skills. It was considered by the distribution of active students in each class.

Learning in this study has several activities. Figure 1 shows how each learning activities have the potential to develop certain facets of research skills. These activities are similar to the stages carried out by scientists in conducting research, so this learning is considered to have supported the development of students' research skills. When APL is used in secondary schools as a learning resource, APL can improve the inquiry-based science learning process (Ford, 2009; Yarden et al., 2015b). APL itself is indeed a form of writing that describes a process of inquiry. By reading APL, students can follow the flow of the research. In addition, the advantage of using APL in schools is to introduce examples of complex, authentic, and sophisticated scientific arguments (Ford, 2009). APL can also support scientific discourse (Koomen et al., 2016) and scientific literacy (Koomen et al., 2016; Yarden et al., 2015a). 


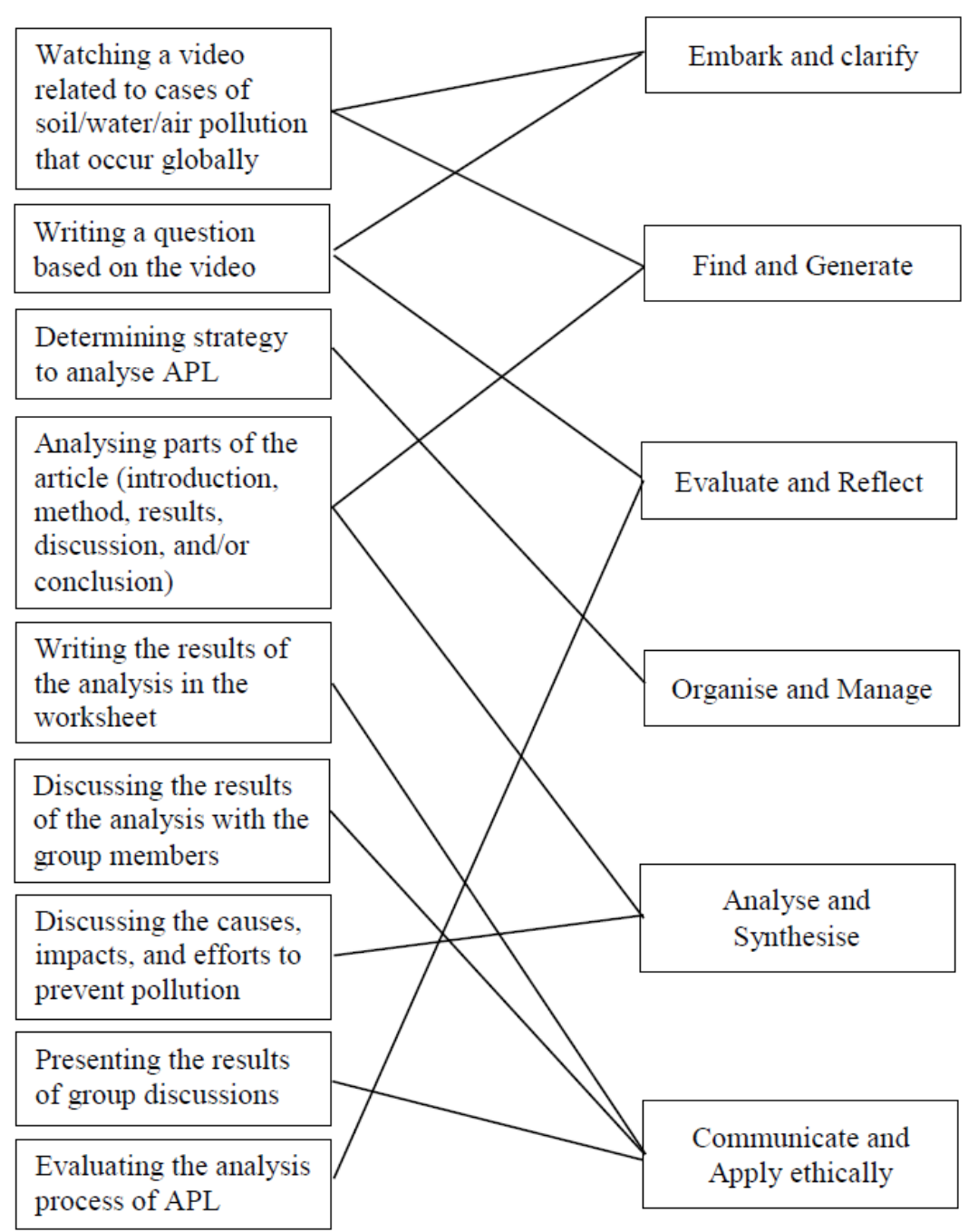

Figure 1. Facets of research skills that might be developed through the learning activities

To test the significance of the development of students' research skills, statistical analyses were performed. Students' research skills were tested before and after the learning in the form of pre-test and post-test. Table 4 shows the descriptive analysis of the research skills score in the two classes at the pre-test and post-test.

Table 4. Descriptive Analysis of Students' Research Skill

\begin{tabular}{lcccc}
\hline \multirow{2}{*}{ Descriptive Statistics } & \multicolumn{2}{c}{ Jigsaw Class } & \multicolumn{2}{c}{ NHT Class } \\
\cline { 2 - 5 } & Pre-test & Post-test & Pre-test & Post-test \\
\hline Number of participants & 17 & 17 & 27 & 27 \\
Mean & 6.86 & 42.81 & 6.59 & 34.57 \\
Standard deviation & 4.62 & 13.58 & 5.12 & 16.26 \\
Minimum Score & 0.00 & 16.67 & 0.00 & 5.56 \\
Maximum Score & 11.11 & 66.67 & 16.67 & 77.78 \\
\hline
\end{tabular}

The average score of students' research skills in both classes at the pre-test was in the very low category. This is in line with our prediction that students' research skills are still low 
based on the level of science process skills (Atmojo, 2012; Fatmawati \& Handhika, 2018; Rahman et al., 2017). It can be also seen that the minimum score in both classes is 0.00 . Meanwhile, the average score of students' research skills at post-test was in a different category. Students in the jigsaw class have an average score of research skills in the medium category. Meanwhile, students in the NHT class have an average score of research skills in the low category. Until the present, we may say that analysing APL using the jigsaw model can offer more significant development toward students' research skills.

The level of students' research skills in both classes in each facet can be seen in Figure 2. At the pre-test, the students' research skills in both classes in most facets were in the very low category. It is not surprising since most students do not have any experience in doing research. Only research skills in the Analyse and Synthesis facet are in a low category. It might be due to this facet having been trained in previous learning when the students were assigned to acquire data or information from a table or graph. Then at the post-test, students' research skills were between the low and medium categories. There was an improvement in all facets. The students' research skills in both classes in the Embark and Clarify facet were in the lowest category compared to other facets. In the research skills tests, students had to determine which research questions and hypotheses that are most appropriate to the research example given. These two terms seem new for the students and they might face difficulties answering them. Perhaps they need more sessions to discuss them. The research skills of students in the jigsaw class on the Organize and Manage facet had the highest score compared to other facets, both in the jigsaw class and in the NHT class. This is possibly a consequence of applying cooperative learning that organizing and managing is a learning activity that stands out in this model. Meanwhile, the highest student research skills in the NHT class are in the Find and Generate facet.

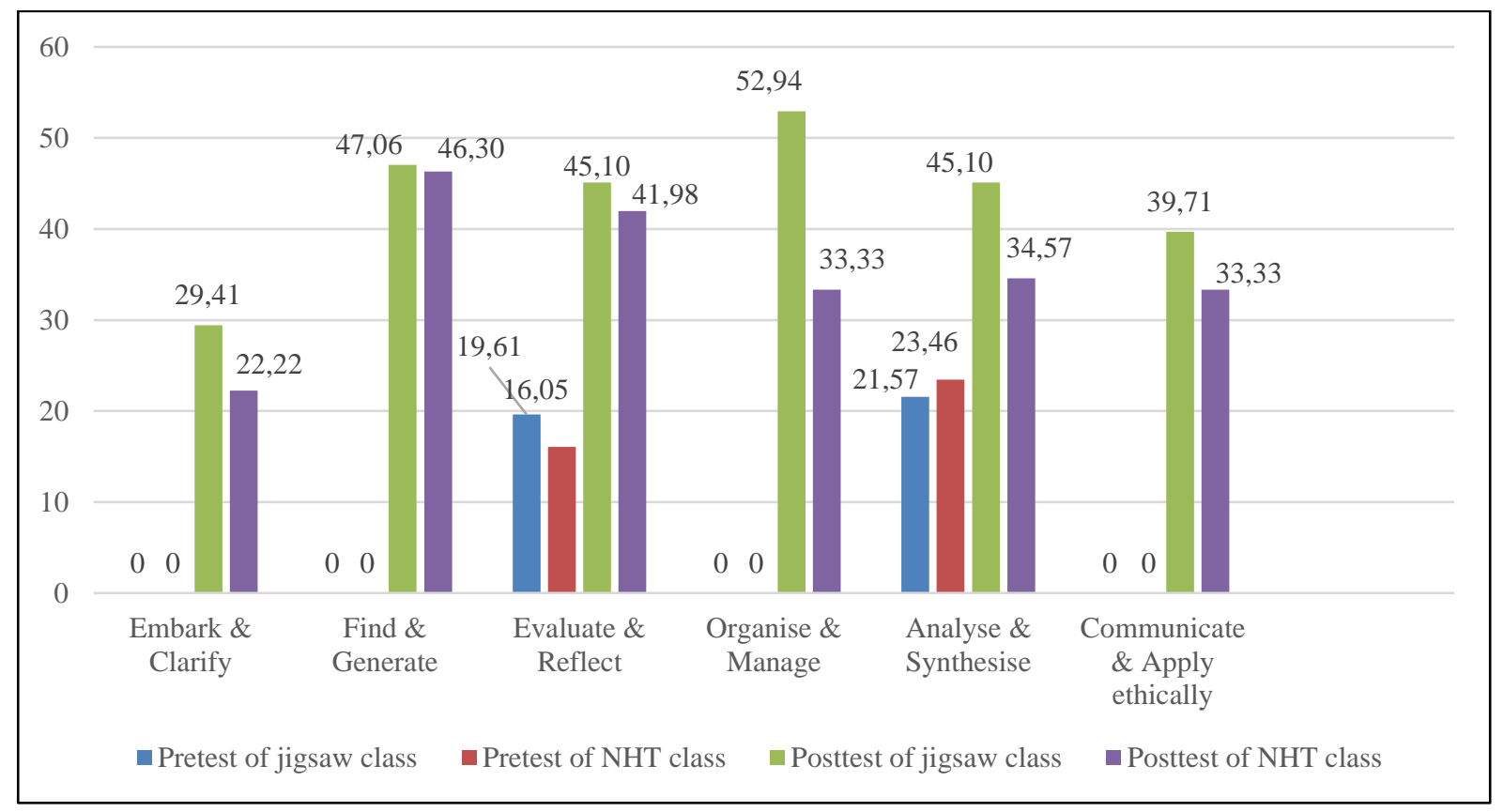

Figure 2. Mean Score of Each Facet of Students' Research Skills 
The mean difference of students' research skills in the jigsaw and NHT classes at the pre-test and post-test can be examined through inferential analysis with a significance level of 0.05. Table 5 shows inferential statistics for this purpose. At the pre-test and post-test, students in the jigsaw and NHT classes possessed an equal research skills level. The result of this inferential analysis indicates that both before and after treatment, the students' research skills in both classes were equal. Thus, there are three possibilities, namely, both are unchanged, both are decreasing or both are developing equally. By comparing the mean of research skills in each class at the pre-test and post-test, it can be straightforwardly said that both are developing. However, the next statistical tests are still required to perform for obtaining more valid evidence.

Table 5. Inferential Analysis of Students' Research Skills of Jigsaw and NHT Class

\begin{tabular}{lcccc}
\hline \multirow{2}{*}{ Test } & \multicolumn{2}{c}{ Pre-test } & \multicolumn{2}{c}{ Post-test } \\
\cline { 2 - 5 } & Jigsaw Class & NHT Class & Jigsaw Class & NHT Class \\
\hline \multirow{2}{*}{$\begin{array}{l}\text { Normality } \\
\text { (Kolmogorov-Smirnov) }\end{array}$} & $\mathrm{P}=0,000$ & $\mathrm{P}=0,000$ & $\mathrm{P}=0,200$ & $\mathrm{P}=0,000$ \\
& Data are not & Data are not & Data are & Data are not \\
normally & normally & normally & normally \\
Homogeneity & distributed & distributed & distributed & distributed \\
(Levene's Test) & $P$-value $=0,927$ & $P$-value $=0,908$ \\
Mean Difference & \multicolumn{2}{c}{ Data are homogeny } & Data are homogeny \\
(Mann-Whitney U Test) & \multicolumn{2}{c}{$P$-value $=0,665$} & \multicolumn{2}{c}{$P$-value $=0,054$} \\
& \multicolumn{2}{c}{ No difference } & \multicolumn{2}{c}{ No difference } \\
\hline
\end{tabular}

Now, we are examining the mean difference of students' research skills at the pre-test and post-test in each class through inferential analysis with a significance level of 0.05. Table 6 shows inferential statistics for this purpose. The Wilcoxon test provides information that there is a significant difference between students' research skills at the pre-test and post-test in the two classes. This confirms the previous statistical analysis. From these two tests, we are confident to say that the use of APL as a science learning resource can develop students' research skills in both classes. Reading and analysing APL means understanding the research flow from introduction to conclusion. Students are considered to have known what the research background at the APL is. Students are also considered to have known what methods, data collection techniques, and data analysis were used, as well as how the researchers drew the conclusions.

Table 6. Inferential Analysis of Students' Research Skills of Pre-test and Post-test

\begin{tabular}{lcccc}
\hline \multirow{2}{*}{ Tests } & \multicolumn{2}{c}{ Jigsaw Class } & \multicolumn{2}{c}{ NHT Class } \\
\cline { 2 - 4 } & Pre-test & Post-test & Pre-test & Post-test \\
\hline \multirow{2}{*}{ Normality } & $\mathrm{P}=0,000$ & $\mathrm{P}=0,200$ & $\mathrm{P}=0,000$ & $\mathrm{P}=0,004$ \\
(Kolmogorov-Smirnov) & Data are not & Data are & Data are not & Data are not \\
& normally & normally & normally & normally \\
Homogeneity & distributed & distributed & distributed & distributed \\
(Levene's Test) & $P$-value $=0,001$ & P-value $=0,002$ \\
Mean Difference & Data are not homogeny & Data are not homogeny \\
(Wilcoxon Rank Test) & \multicolumn{2}{c}{$P$-value $=0,000$} & P-value $=0,000$ \\
\hline
\end{tabular}


Mastery of skills will be more straightforward to achieve with a learning process through experience (Lander et al., 2019). Then, authentic science provides students an opportunity to practice research skills (Labouta et al., 2018; Ward et al., 2016). Authentic science using other learning sources has also been shown to develop research skills (Xu et al., 2012). Assignments in the form of collecting information, can also provide experience doing research and develop students' research skills (Meerah \& Arsad, 2010). What was recently revealed by this study seems to be in line with the previous study. The development of research skills in both classes seems equal. This means the use of the jigsaw or NHT cooperative learning model does not seem to make a significant difference in developing students' research skills through the use of APL in authentic science. Therefore, science teachers can use any of them to develop their students' research skills.

In case the science teachers need to choose only one learning method to use in developing their students' research skills by analysing APL, perhaps we need to determine which is more effective than another. To get the answer, the effect size was calculated. It was chosen to wrap up all data from the pre-test and post-test of the two classes. Even though both classes in this study are considered practical classes, since the average score in the jigsaw class is higher than NHT class, we put the jigsaw class as the experimental one. From the calculation, the effect size is 0.5 (Lenhard \& Lenhard, 2016). This value can be interpreted as an intermediate effect. Therefore, we may say that the jigsaw is more effective than the NHT in developing students' research skills by analysing APL. The students in the jigsaw class perceived the analysing APL activity as more similar to what the researchers do (Hidayat et al., 2021).

Research skills development since junior high school is really required. It cannot be achieved by only the temporary development program. It can be through existing learning programs or through special programs (Hughes, 2019). Science teachers must provide the development program throughout the year. The proof is that learning in senior high school which has been specifically designed for the development of research skills was not able to make all students master all facets of research skills (Roito et al., 2019). Moreover, it was also found that bachelor graduates did not fully master all facets of research skills. Even though research skills development has been explicitly provided during college (Ain et al., 2019). Conceptualizing and facilitating the development of students' research skills is the task of all educators (Willison \& O'Regan, 2007). There are several strategies in developing students' research skills. One of them is through inquiry-based learning (Rodríguez et al., 2019). Particularly, the development of student research skills can be through research-based learning. In other words, students are granted the opportunity to conduct research (Gilmore et al., 2015; Meerah \& Arsad, 2010; Odera et al., 2015; Wisker, 2019). This study has revealed that students' research skills development can be through an authentic science approach that uses APL as the learning resource. 


\section{Conclusion}

Data analysis in this study found that the use of APL in science learning using a jigsaw and NHT models could develop students' research skills. The research skills in both classes showed significant improvement. Furthermore, the jigsaw model is more recommended to use. Although the number of participants is few, some findings in this study showed that using APL in science class has great potential in developing students' research skills. In addition, we also believe that it can promote the scientific method. For further research, we suggest conducting the research in face-to-face learning in order to obtain maximum participation of the research subject and more data to analyze.

\section{Acknowledgment}

I would like to thank the Indonesia Endowment Fund for Education (LPDP) for fully funding my study at Universitas Pendidikan Indonesia. I also thank Mr. Sukardi and his students who have supported and were willing to be participants in this research.

\section{References}

Achiam, M., Simony, L., \& Lindow, B. E. K. (2016). Objects prompt authentic scientific activities among learners in a museum programme. International Journal of Science Education, 38(6), 1012-1035. https://doi.org/10.1080/09500693.2016.1178869

Ain, C. T., Sabir, F., \& Willison, J. (2019). Research skills that men and women developed at university and then used in workplaces. Studies in Higher Education, 44(12), 23462358. https://doi.org/10.1080/03075079.2018.1496412

Anker-Hansen, J., \& Andrée, M. (2019). In Pursuit of Authenticity in Science Education. Nordina, 15(1), 498-510.

Ariely, M., Livnat, Z., \& Yarden, A. (2019). Analyzing the Language of an Adapted Primary Literature Article. Science \& Education, 28(1-2), 63-85. https://doi.org/10.1007/s11191019-00033-5

Atmojo, S. E. (2012). Profil Keterampilan Proses Sains dan Apresiasi Siswa terhadap Profesi Pengrajin Tempe dalam Pembelajaran IPA Berpendekatan Etnosains. Jurnal Pendidikan IPA Indonesia, 1(2), 115-122. https://journal.unnes.ac.id/nju/index.php/jpii/article/view/2128/2229

Ball, P. (2017). It's not just you: science papers are getting harder to read. Nature News. https://doi.org/10.1038/nature.2017.21751

Broder, E. D., Guilbert, K. E., Tinghitella, R. M., Murphy, S. M., Ghalambor, C. K., \& Angeloni, L. M. (2019). Authentic science with dissemination increases self-efficacy of middle school students. Integrative and Comparative Biology. https://doi.org/10.1093/icb/icz140

Buxton, C. A. (2006). Creating contextually authentic science in a "low-performing" urban elementary school. Journal of Research in Science Teaching, 43(7), 695-721. https://doi.org/10.1002/tea.20105

Chapman, A., \& Feldman, A. (2017). Cultivation of science identity through authentic science in an urban high school classroom. Cultural Studies of Science Education, 12(2), 469491. https://doi.org/10.1007/s11422-015-9723-3

Crawford, B. (2013). Authentic Science. In R. Gunstone (Ed.), Encyclopedia of Science Education (pp. 1-3). Springer Netherlands. https://doi.org/10.1007/978-94-007-61650_144-2 
Dumford, A. D., \& Miller, A. L. (2018). Online learning in higher education: exploring advantages and disadvantages for engagement. Journal of Computing in Higher Education, 30(3), 452-465. https://doi.org/10.1007/s12528-018-9179-z

Fatimah, S. (2018). Salip Singapura, Publikasi Ilmiah Indonesia Peringkat 2 ASEAN. https://news.okezone.com/read/2018/04/11/65/1885240/salip-singapura-publikasiilmiah-indonesia-peringkat-2-asean

Fatmawati, I., \& Handhika, J. (2018). Profil Keterampilan Proses Sains di SMP Negeri 1 Wungu. Seminar Nasional Pendidikan Fisika IV 2018, 279-282.

Ford, D. J. (2009). Promises and Challenges for the Use of Adapted Primary Literature in Science Curricula: Commentary. Research in Science Education, 39(3), 385-390. https://doi.org/10.1007/s11165-008-9115-8

Fraenkel, J. R., Wallen, N. E., \& Hyun, H. H. (2012). How to Design and Evaluate Research in Education. McGraw-Hill.

Gilmore, J., Vieyra, M., Timmerman, B., Feldon, D., \& Maher, M. (2015). The Relationship between Undergraduate Research Participation and Subsequent Research Performance of Early Career STEM Graduate Students. The Journal of Higher Education, 86(6), 834863. https://doi.org/10.1080/00221546.2015.11777386

Glackin, M. (2016). 'Risky fun' or 'Authentic science'? How teachers' beliefs influence their practice during a professional development programme on outdoor learning. International Journal of Science Education, 38(3), 409-433. https://doi.org/10.1080/09500693.2016.1145368

Hellgren, J. M., \& Lindberg, S. (2017). Motivating students with authentic science experiences: changes in motivation for school science. Research in Science and Technological Education, 35(4), 409-426. https://doi.org/10.1080/02635143.2017.1322572

Hidayat, T., Rustaman, N., \& Shidiq, A. S. (2020). Science Teachers' Perception of APL: What and How. Proceedings of the 2020 8th International Conference on Information and Education Technology, 169-173. https://doi.org/10.1145/3395245.3396423

Hidayat, T., Rustaman, N., \& Siahaan, P. (2021). Adapted Primary Literature in Authentic Science: Students' Perception. Journal of Science Learning, 4(4), 309-315. https://doi.org/https://doi.org/10.17509/jsl.v4i4.32731

Hughes, G. (2019). Developing student research capability for a 'post-truth' world: three challenges for integrating research across taught programmes. Teaching in Higher Education, 24(3), 394-411. https://doi.org/10.1080/13562517.2018.1541173

Janacsek, K., Fiser, J., \& Nemeth, D. (2012). The best time to acquire new skills: age-related differences in implicit sequence learning across the human lifespan. Developmental Science, 15(4), 496-505. https://doi.org/10.1111/j.1467-7687.2012.01150.x

Juhász, D., \& Németh, D. (2018). Age-related and gender differences in conslidation of implicit sequence learning between 7 and 29 years of age. Psychiatria Hungarica : A Magyar Pszichiatriai Tarsasag Tudomanyos Folyoirata, 33(2), 125-137.

Koomen, M. H., Rodriguez, E., Hoffman, A., Petersen, C., \& Oberhauser, K. (2018). Authentic science with citizen science and student-driven science fair projects. Science Education, 102(3), 593-644. https://doi.org/10.1002/sce.21335

Koomen, M. H., Weaver, S., Blair, R. B., \& Oberhauser, K. S. (2016). Disciplinary literacy in the science classroom: Using adaptive primary literature. Journal of Research in Science Teaching, 53(6), 847-894. https://doi.org/10.1002/tea.21317

Labouta, H. I., Kenny, N. A., Li, R., Anikovskiy, M., Reid, L., \& Cramb, D. T. (2018). Learning science by doing science: an authentic science process-learning model in postsecondary education. International Journal of Science Education, 40(12), 14761492. https://doi.org/10.1080/09500693.2018.1484966 
Lander, J., Seeho, S., \& Foster, K. (2019). Learning Practical Research Skills Using An Academic Paper Framework - An Innovative, Integrated Approach. Health Professions Education, 5(2), 136-145. https://doi.org/10.1016/j.hpe.2018.06.002

Landreau, J. (2011). Research: Why Wait Till High School? Phi Delta Kappan, 92(6), 55-57. https://doi.org/10.1177/003172171109200612

Lenhard, W., \& Lenhard, A. (2016). Computation of effect sizes. Psychometrica. https://doi.org/10.13140/RG.2.2.17823.92329

Machluf, Y., Gelbart, H., Ben-Dor, S., \& Yarden, A. (2017). Making authentic science accessible-the benefits and challenges of integrating bioinformatics into a high-school science curriculum. Briefings in Bioinformatics, 18(1), 145-159. https://doi.org/10.1093/bib/bbv113

Meerah, T. S. M., \& Arsad, N. M. (2010). Developing research skills at secondary school. Procedia - Social and Behavioral Sciences, 9, 512-516. https://doi.org/10.1016/j.sbspro.2010.12.189

Meerah, T. S. M., Osman, K., Zakaria, E., Ikhsan, Z. H., Krish, P., Lian, D. K. C., \& Mahmod, D. (2012). Measuring Graduate Students Research Skills. Procedia - Social and Behavioral Sciences, 60, 626-629. https://doi.org/10.1016/j.sbspro.2012.09.433

Minium, E. D., King, B. M., \& Bear, G. (1993). Statistical Reasoning in Psychology and Education (Third Edit). John Wiley \& Sons.

Morgan, H. (2020). Best Practices for Implementing Remote Learning during a Pandemic. The Clearing House: A Journal of Educational Strategies, Issues and Ideas, 93(3), 135141. https://doi.org/10.1080/00098655.2020.1751480

Munn, M., Knuth, R., Van Horne, K., Shouse, A. W., \& Levias, S. (2017). How do you like your science, wet or dry? How two lab experiences influence student understanding of science concepts and perceptions of authentic scientific practice. CBE Life Sciences Education, 16(2), ar39. https://doi.org/10.1187/cbe.16-04-0158

Odera, E., Lamm, A., Odera, L., Duryea, M., \& Davis, J. (2015). Understanding how research experiences foster undergraduate research skill development and influence STEM career choice. NACTA Journal, 59(3), 180.

Olitsky, S., Becker, E. A., Jayo, I., Vinogradov, P., \& Montcalmo, J. (2018). Constructing "Authentic" Science: Results from a University/High School Collaboration Integrating Digital Storytelling and Social Networking. Research in Science Education, 1-24. https://doi.org/10.1007/s11165-018-9699-6

Phillips, L. M., \& Norris, S. P. (2009). Bridging the Gap Between the Language of Science and the Language of School Science Through the Use of Adapted Primary Literature. Research in Science Education, 39(3), 313-319. https://doi.org/10.1007/s11165-0089111-z

Rahman, A., Wahyuni, I., \& Rifqiawati, I. (2017). Profil Keterampilan Proses Sains dan Sikap Ilmiah Siswa di SMP Satu Atap Pulau Tunda. School Education Journal, 7(1), 17.

Ristekdikti. (2018). Publikasi Indonesia Masih Minim Pembaruan. https://risbang.ristekdikti.go.id/publikasi/berita-media/publikasi-indonesia-masih-minimpembaruan/

Rivera Maulucci, M. S., Brown, B. A., Grey, S. T., \& Sullivan, S. (2014). Urban middle school students' reflections on authentic science inquiry. Journal of Research in Science Teaching, 51(9), 1119-1149. https://doi.org/10.1002/tea.21167

Rodríguez, G., Pérez, N., Núñez, G., Baños, J. E., \& Carrió, M. (2019). Developing creative and research skills through an open and interprofessional inquiry-based learning course. BMC Medical Education, 19(1), 134. https://doi.org/10.1186/s12909-019-1563-5

Roito, E., Solihat, R., \& Wulan, A. R. (2019). Pencapaian Keterampilan Meneliti Abad Ke-21 
Peserta Didik SMA pada Pembelajaran Ekosistem melalui Step-By-Step Model Experiment. Assimilation: Indonesian Journal of Biology Education, 2(1), 14-18. Scimago Lab. (2018). Scimago Journal \& Country Rank. SJR - SCImago Journal \& Country Rank. https://www.scimagojr.com/countryrank.php

Silalahi, T. F., \& Hutauruk, A. F. (2020). The Application of Cooperative Learning Model during Online Learning in the Pandemic Period. Budapest International Research and Critics Institute (BIRCI-Journal): Humanities and Social Sciences, 3(3), 1683-1691.

Siswanto, Yusiran, \& Fajarudin, M. F. (2016). Keterampilan Proses Sains dan Kemandirian Belajar Siswa: Profil dan Setting Pembelajaran untuk Melatihkannya. Gravity, 2(2), 190-202.

Subekti, H., Purnomo, A. R., Susilo, H., Ibrohim, I., \& Suwono, H. (2018). Analysis of preservice science teacher information literacy towards research skills. Journal of Physics: Conference Series, 1006(1), 12009. https://doi.org/10.1088/17426596/1006/1/012009

Sugiyono. (2010). Metode Penelitian Pendidikan: Pendekatan Kuantitatif, Kualitatif, dan $R \& D$. Penerbit Alfabeta.

Timmerman, B. C., Feldon, D., Maher, M., Strickland, D., \& Gilmore, J. (2013).

Performance-based assessment of graduate student research skills: timing, trajectory, and potential thresholds. Studies in Higher Education, 38(5), 693-710.

https://doi.org/10.1080/03075079.2011.590971

Tsybulsky, D. (2019). Students meet authentic science: the valence and foci of experiences reported by high-school biology students regarding their participation in a science outreach programme. International Journal of Science Education, 41(5), 567-585. https://doi.org/10.1080/09500693.2019.1570380

Ward, T. J., Delaloye, N., Adams, E. R., Ware, D., Vanek, D., Knuth, R., Hester, C. L., Marra, N. N., \& Holian, A. (2016). Air Toxics Under the Big Sky: examining the effectiveness of authentic scientific research on high school students' science skills and interest. International Journal of Science Education, 38(6), 905-921. https://doi.org/10.1080/09500693.2016.1167984

Wargadinata, W., Maimunah, I., Eva, D., \& Rofiq, Z. (2020). Student's responses on learning in the early COVID-19 pandemic. Tadris: Journal of Education and Teacher Training, 5(1), 141-153.

Willison, J., \& O’Regan, K. (2007). Commonly known, commonly not known, totally unknown: a framework for students becoming researchers. Higher Education Research \& Development, 26(4), 393-409. https://doi.org/10.1080/07294360701658609

Wisker, G. (2019). Developing Scientific Thinking and Research Skills Through the Research Thesis or Dissertation. In M. Murtonen \& K. Balloo (Eds.), Redefining Scientific

Thinking for Higher Education: Higher-Order Thinking, Evidence-Based Reasoning and Research Skills (pp. 203-232). Springer International Publishing. https://doi.org/10.1007/978-3-030-24215-2_9

World Economic Forum. (2018). The Global Competitiveness Report 2018 (K. Schwab (ed.)). World Economic Forum.

http://www3.weforum.org/docs/GCR2018/05FullReport/TheGlobalCompetitivenessRep ort2018.pdf

$\mathrm{Xu}$, J., Dinwoodie, J., \& Chang, C.-H. (2012). Seeing is believing: Developing research skills in international maritime students through authentic learning. The International Journal of Management Education, 10(1), 50-60.

https://doi.org/https://doi.org/10.1016/j.ijme.2012.02.005

Yarden, A. (2009). Reading Scientific Texts: Adapting Primary Literature for Promoting Scientific Literacy. Research in Science Education, 39(3), 307-311. 
https://doi.org/10.1007/s11165-009-9124-2

Yarden, A., Norris, S. P., \& Phillips, L. M. (2015a). Adapting Primary Literature for Promoting Scientific Literacy. In A. Yarden, S. P. Norris, \& L. M. Phillips (Eds.), Adapted Primary Literature: The Use of Authentic Scientific Texts in Secondary Schools (pp. 15-31). Springer Netherlands. https://doi.org/10.1007/978-94-017-9759-7_2

Yarden, A., Norris, S. P., \& Phillips, L. M. (2015b). APL and Reading in Science Classrooms. In A. Yarden, S. P. Norris, \& L. M. Phillips (Eds.), Adapted Primary Literature: The Use of Authentic Scientific Texts in Secondary Schools (pp. 59-80). Springer Netherlands. https://doi.org/10.1007/978-94-017-9759-7_4

Yarden, A., Norris, S. P., \& Phillips, L. M. (2015c). Creating and Using Adapted Primary Literature. In A. Yarden, S. P. Norris, \& L. M. Phillips (Eds.), Adapted Primary

Literature: The Use of Authentic Scientific Texts in Secondary Schools (pp. 83-108). Springer Netherlands. https://doi.org/10.1007/978-94-017-9759-7_5 